\title{
Phycocyanin as Potential Natural Dye for its Use in Photovoltaic Cells
}

\author{
Paula Enciso ${ }^{1}$, Franco M. Cabrerizo ${ }^{2}$, Jorge S. Gancheff ${ }^{3}$, Pablo A. Denis ${ }^{4}$ and \\ María Fernanda Cerdá ${ }^{1, *}$
}

${ }^{1}$ Laboratorio de Biomateriales, Facultad de Ciencias, IQB, UdelaR, Iguá 4225, 11400, Montevideo, Uruguay

${ }^{2}$ Instituto de Investigaciones Biotecnológicas - Instituto Tecnológico de Chascomús (IIB-INTECH), Universidad Nacional de San Martín (UNSAM) - Consejo Nacional de Investigaciones Científicas y Técnicas (CONICET), Intendente Marino Km 8.2, CC 164 (B7130IWA), Chascomús, Buenos Aires, Argentina

${ }^{3}$ Cátedra de Química Inorgánica, Departamento "Estrella Campos", Facultad de Química, UdelaR, Gral, Flores 2124, Montevideo, Uruguay

${ }^{4}$ DETEMA, Facultad de Química, UdelaR, Gral, Flores 2124, Montevideo, Uruguay

\begin{abstract}
Phycocyanin, a blue protein extracted from Spirulina spp, shows promising characteristics that made it suitable for its use as natural dye in photovoltaic devices as the dye sensitized solar cells. In this work, a study of the aqueous solution-phase photochemistry, photophysics, spectroscopy, voltammetry and thermal stability of phycocyanin is presented. Suitable redox potentials (Eox $=1.2 \mathrm{~V}$ vs. $\mathrm{Ag} / \mathrm{AgCl}$ ) and a value of $1.96 \mathrm{~V}$ for $\mathrm{E}_{0,0}$ (i.e., the energy difference between the vibrationally relaxed levels of the first electronic excited state, $S_{1}$, and the ground state, $S_{0}$ of phycocyanin), allows the calculation of energetic profiles that in comparison with the conduction band of the anatase$\mathrm{TiO}_{2}$ and $\mathrm{I}^{2} / \mathrm{I}_{3}$ electrolyte, could predict electron transfer with these components of the cell.

The data reported herein should not only help to evaluate the potential use of phycocyanin as sensitizer for solar cells, but should also help in the development of novel solar cells where the photoinduced behavior of this protein can be controlled.
\end{abstract}

Keywords: Natural dye, DSSC, energy level diagram, phycocyanin.

\section{INTRODUCTION}

Dye sensitized solar cells (DSSC) had an explosive growing since they were developed by Grätzel near thirty years ago. In the beginning, they were based on natural dyes, as those used by plants in photosynthetic paths. Today, most of efforts and research are conducting around four major points in order to improve energy efficiency conversion: the search of the best dye, catalytic material for the counter electrode, redox couples in electrolytes, and the semiconductor material.

DSSC are of great interest, because of the environmental advantages of their use. First of all, they are based on the use of solar energy, the best alternative to fossil fuel because of the wide availability of this source. In addition, they are also interesting because they provide an alternative to silicon based devices, with conversion efficiency quite close to those get with commercial ones, and without the disadvantages linked to the extraction of silicon.

*Address correspondence to this author at the Laboratorio de Biomateriales, IQB, Facultad de Ciencias, UdelaR, Igua 4225, 11400, Montevideo, Uruguay; Tel/Fax: +598 25250749; E-mail: fcerda@fcien.edu.uy
DSSC are photoelectrochemical cells that resemble natural photosynthesis, because they use organic dyes to harvest the incident light, leading a flow of electrons. Moreover, such devices use multiple layers to enhance both the light absorption and electron collection efficiency [1-3]. The cell is composed by two electrodes, one containing the dye adsorbed on $\mathrm{TiO}_{2}$, distributed uniformly on a glass plate which has previously been coated with a thin conductive and transparent layer of tin dioxide as ITO or FTO. The $\mathrm{TiO}_{2} /$ glass plate electrode is dipped into a solution of a dye in order to get its adsorption. For this purpose many dyes can be utilized, but they must possess a chemical group which can be attached and adsorbed onto the titanium dioxide surface, and they must have energy levels at the proper positions necessary for electron injection and photosensitization. To complete the device, a drop of liquid electrolyte containing iodide is placed onto the dye/TiO $/$ FTO electrode and a counter electrode of conductive glass, which has been coated with a thin catalytic layer of platinum or carbon, is placed on top [4-6].

One remarkable point is the fact that the dye layer is very thin and almost all of the excited electrons produced upon photon absorption are injected into the $\mathrm{TiO}_{2}$. Moreover, this photosensitized process takes 
place under polychromatic incident light (i.e., in the wide range of wavelengths absorbed by the dye).

The electrons lost by the dye are replaced by the mediator which is the iodide ion in the electrolyte solution. The oxidized mediator forms iodine or triiodide, which in turn obtains an electron at the counter electrode.

Dye $+\mathrm{h} v \rightarrow[\text { Dye }]^{*}$

$[\text { Dye }]^{*}+\mathrm{TiO}_{2} \rightarrow \mathrm{e}^{-}\left(\mathrm{TiO}_{2}\right)+[\text { Dye }]^{\bullet+}$

$[\text { Dye }]^{\bullet+}+3 / 2 I^{-} \rightarrow$ Dye $+1 / 2 I_{3}$

$1 / 2 \mathrm{I}_{3}{ }^{-}+\mathrm{e}^{-}$(counter electrode $) \rightarrow 3 / 2 \mathrm{I}^{-}$

The dye must follow certain characteristics to be chosen as suitable pigment for a DSSC. In first place, electron transfer processes between the excited state of the dye and the conduction band of the $\mathrm{TiO}_{2}$ must be possible. In second place, the oxidized dye must be regenerated at the counter electrode due to the presence of the redox couple in the electrolyte. And in third place, the dye must be stable with time and temperature.

Literature on the topic showed a great increase, nevertheless reported efficiency are still low (around 12 $\%)[5,7-15]$ and, to the best of our knowledge, new dyes needs to be assessed. In this regard, the use of natural dyes represents an attractive alternative, especially for emergent countries because the low cost of fabrication of cells based on their use, besides the environmental benefits related to their employment. Literature reported that natural dyes based cells were efficiency rises until $2 \%$, with good stability and manufactory low costs [16-21].

Many natural dyes extracted from flowers, leaves, fruits and beverages are used as sensitizers for DSSC, as reported. Anthocyanins, with an absorption peak of ca. $540 \mathrm{~nm}$, chlorophyll at $665 \mathrm{~nm}$, xanthophyll, flavone, carotene (within the $400-500 \mathrm{~nm}$ visible range) are examples of compounds responsible for the absorption peaks present at such natural compounds.

Some of them display high extinction coefficients (ca. $10^{5} \mathrm{~L} \mathrm{~mol}^{-1} \mathrm{~cm}^{-1}$ ), with interesting characteristics for the use in DSSC. In this line, phycocyanin from Spirulina has promising characteristics, i.e. high absorption coefficients in the visible region (extinction coefficient at $615 \mathrm{~nm}=2.3 \cdot 10^{5} \mathrm{~L} \mathrm{~mol}^{-1} \mathrm{~cm}^{-1}$ ) [22].
But the interest in Spirulina is growing, because its potential use as biofuel. The use of Spirulina with this purpose is widely reported [23-32]. Among the biofuels, first generation ones extracted from food and oil crops have attained economic levels of production. However, the use of first generation biofuels has generated a lot of controversy, mainly due to their impact on global food markets and on food security, especially with regards to the most vulnerable regions of the world economy. For this reason, microalgae-derived biofuels are focusing more interest. Aquatic microalgae are ideal for producing liquid fuels, because of their rapid growth, high biomass yields, product diversity, and ease of harvest from ponds or closed photo bioreactor systems. For these, on many countries growing interest is now focused on the development of third generation biofuels obtained from microalgae organisms. In particular, countries as Brazil (one of the largest biofuel producers) and Argentina are geographically situated in climatic zones favorable for large-scale cultivation of algae for biofuel production, where the optimal temperature for growing many micro algae is between 20 and $30{ }^{\circ} \mathrm{C}$. And neighbor's countries are also starting to follow Brazilian steps [33-35]. Additionally, the growth of Spirulina is very easy, and grows exponentially under optimal conditions, in either marine or freshwater environments.

In this work, we characterize phycocyanin extracted from Spirulina spp. Phycocyanin is a blue protein, 36 $\mathrm{kDa}$, containing a chromophore with carboxylic moieties, suitable to establish bonds with the $\mathrm{TiO}_{2}$ adsorbed on the conductive transparent electrode.

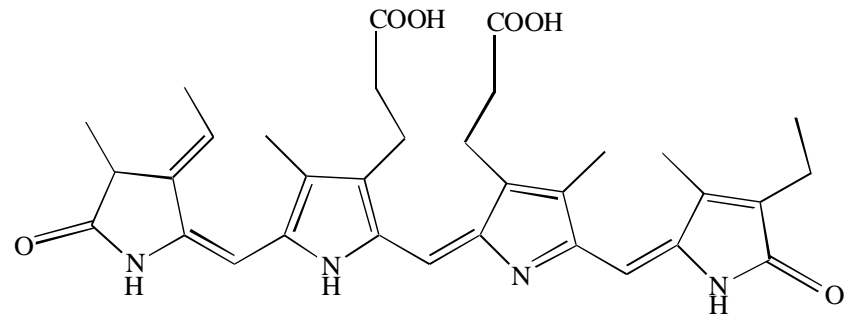

The chromophore is responsible for the high extinction coefficients of the protein when adopting a lineal conformation structure, an important parameter for a dye suitable for a DSSC [36-37].

\section{METHODS}

\subsection{Materials and Experimental Conditions}

Phycocyanin was extracted from commercial capsules of Spirulina spp. UV-vis measurements were 
carried out at a Shimadzu UV-1603, in the $200-800 \mathrm{~nm}$ range. Fluorescence data were obtained from a Synergy H1 268413. Cyclic voltammetric measurements were performed at a $\mathrm{CHI} 604 \mathrm{E}$ at potential scan rates $\mathrm{v}$ between 0.01 and $0.1 \mathrm{Vs}^{-1}$, at room temperature, using an Au-pc working electrode (0.0707 $\mathrm{cm}^{2}$ geometric area), an $\mathrm{Ag} / \mathrm{AgCl}$ as reference $(\mathrm{E}=0.195 \mathrm{~V}$ vs. SHE) and graphite as counter electrode. All potential in the text are referred to this one.

MilliQ water and reagent grade chemicals were used. $\mathrm{NaClO}_{4}, \mathrm{Nal}$, 3-methoxy propionitrile and ethylene glycol were purchased from Sigma-Aldrich and used without further treatment.

\subsection{Phycocyanin Extraction and Purification Procedure}

To extract phycocyanin, contain of 3 capsules (about $1 \mathrm{~g}$ ) is firstly mixed with $20 \mathrm{ml}$ of water. The mixture is centrifuged at $5000 \mathrm{~g}$ for $20 \mathrm{~min}$. To further purify the phycocyanin, $\left(\mathrm{NH}_{4}\right)_{2} \mathrm{SO}_{4}$ is added to the extract to get a $20 \%$ saturated solution. The solution is kept at $0{ }^{\circ} \mathrm{C}$ during $30 \mathrm{~min}$ and centrifuged at $5000 \mathrm{~g}$ for $20 \mathrm{~min}$. More $\left(\mathrm{NH}_{4}\right)_{2} \mathrm{SO}_{4}$ is added to the supernatant to get a $50 \%$ saturated solution, and it is centrifuged once again.

The procedure is followed by UV-visible measurements, and the fraction with the highest $\mathrm{Abs}_{621} / \mathrm{Abs}_{280}$ ratio is selected. In order to get a salt-free phycocyanin aqueous solution, the last step includes exclusion chromatography using Sephadex G-25. Finally, the water is removed by lyophilization.

\subsection{Fluorescence Quantum Yield Determination}

Fluorescence measurements were performed as it was described elsewhere [38]. Briefly, steady-state spectra were recorded by using a Horiba-Jobin-Yvon spectrofluorometer. Corrected fluorescence spectra were recorded in a $1 \mathrm{~cm}$ path length quartz cell at room temperature. Fluorescence quantum yields were determined from the corrected fluorescence spectra, integrated over the entire emission profile, using Rhodamine Bin ethanol as a reference $\left(\Phi_{F}=0.64\right)$. To avoid inner filter effects, the absorbance of the solutions, at the excitation wavelength, was kept below 0.10 [39].

\section{RESULTS AND DISCUSSION}

\subsection{Spectroscopic Characterization of Phyco- cyanin by Visible Absorption and Fluorescence Emission}

UV-visible spectrum of phycocyanin in aqueous solution showed the presence of two maxima centered at 410 and $619 \mathrm{~nm}$. No significant changes were detected in the spectra when recording in the presence of 3-methoxypropionitrile or ethylene glycol up to $50 \%$, solvents commonly used in assembling DSSC (results not shown). It is to be mentioned, that the values of $\varepsilon$ in the above mentioned non-aqueous solvents were slightly lower than in water.

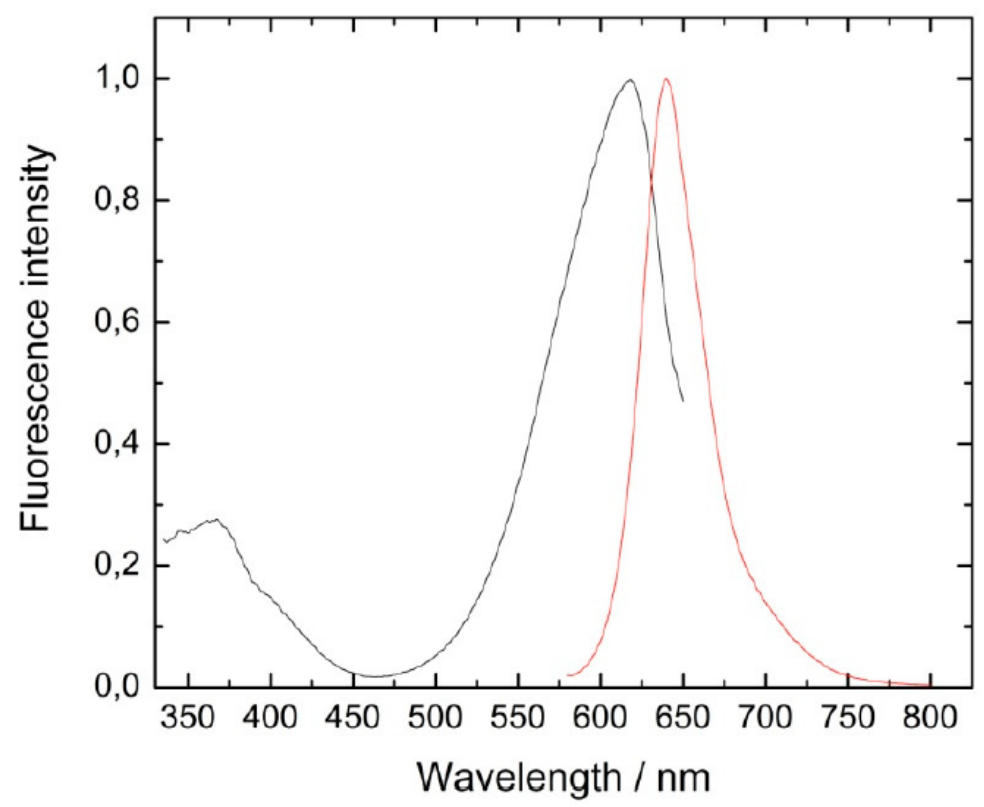

Figure 1: Normalized excitation spectra (black line, emission wavelength, $\lambda_{\mathrm{em}}$, of $640 \mathrm{~nm}$ ) and fluorescence emission spectra (red line, excitation wavelength, $\lambda_{\mathrm{ex}}$, of $530 \mathrm{~nm}$ ) of an aqueous solution of phycocyanin. 
In addition, emission and excitation spectra of aqueous solution of phycocyanin were recorded (Figure 1). Briefly, the emission spectrum shows a sharp band centered at $640 \mathrm{~nm}$ upon excitation of the lowest energy absorption band. The corresponding quantum yield of fluorescence value $\left(\Phi_{\mathrm{F}}\right)$ measured at room temperature was $0.61 \pm 0.06$. This value is within the range of $\Phi_{\mathrm{F}}$ values reported in the literature for $\mathrm{C}$ phycocyanin cyanobacteria [40]. On the other hand, the excitation spectrum shows two bands centered at 364 $\mathrm{nm}$ and $618 \mathrm{~nm}$, respectively, results that are also in good agreement with those reported in the literature.

It is worth mentioned that normalized excitation and fluorescence emission spectra show an intersection at $634 \mathrm{~nm}$. As a consequence, a value of $1.96 \mathrm{eV}$ for the $\mathrm{E}_{0,0}$ could be calculated from the Planck's equation.

\subsection{Cyclic Voltammetric Measurements} change in the presence of phycocyanin with respect to those obtained in the supporting electrolyte. As can be observed in Figure 2, a diminution in the anodic and cathodic contributions related to O-adsorption/ desorption is detected when the blue protein is present.

This is explained by the adsorption of phycocyanin to gold surface, as can also be confirmed by the Ipa vs. $v$ (anodic peak contribution vs. potential scan rate) linear relationship. An anodic contribution related to oxidation of phycocyanin is observed at $1.2 \mathrm{~V}$, with the counter peak at ca. $0.3 \mathrm{~V}$.

To understand the situation, it is important to consider some facts related to the structure of the
Cyclic voltammetric profiles showed an important

protein. In phycocyanin, the chromophore is linked to the protein through the sulfur group of a cystein and therefore, both carboxylic groups remain free and exposed to the solution or to the surface electrode.

As it is known, carboxylic group can be adsorbed onto gold surfaces from ca. $0.4 \mathrm{~V}$ [41-44]. This adsorption is negligible for sufficiently cathodic electrode potentials and, along with the increase in the potential, an increase in the adsorption is observed. This increase reaches its maximum value in the region where the electro oxidation of the metallic surfaces commences, and even in the oxygen region of the electrode potentials, there is still easily measurable adsorption. Adsorption of acid is a result of a competition between the adsorption of water and carboxylic moieties. The adsorption process of acid is reversible; whatever amount of adsorbate is formed at lower potentials it tends to desorbs from the surface at utmost positive potentials. Adsorption on gold may involve the formation of a chemical bond between the molecule and the surface and therefore, the adsorption process is slow.

The anodic peak at $1.2 \mathrm{~V}$ can be assigned to the irreversible oxidation of the carboxylate group to $\mathrm{CO}_{2}$ in the O-electroadsorption potential region [41-42, 45].

It is interesting to point out that adsorption of $-\mathrm{COO}$ moiety starts at lower potentials than O-electrosorption from water molecules. This statement is based in the fact that the $0.6 \mathrm{~V}$ peak can be associated to the latter process because it is also observed in the supporting electrolyte in the absence of phycocyanin. Moreover, when the gold surface is covered with the adsorbed

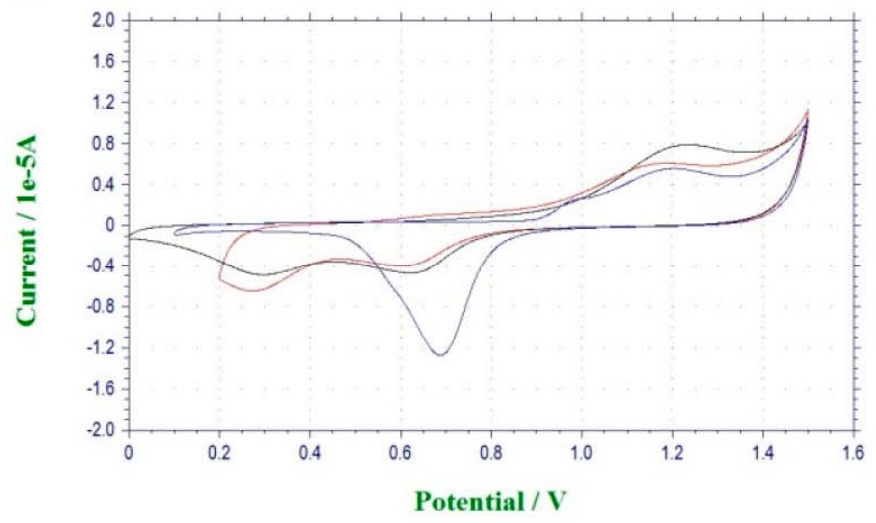

a)

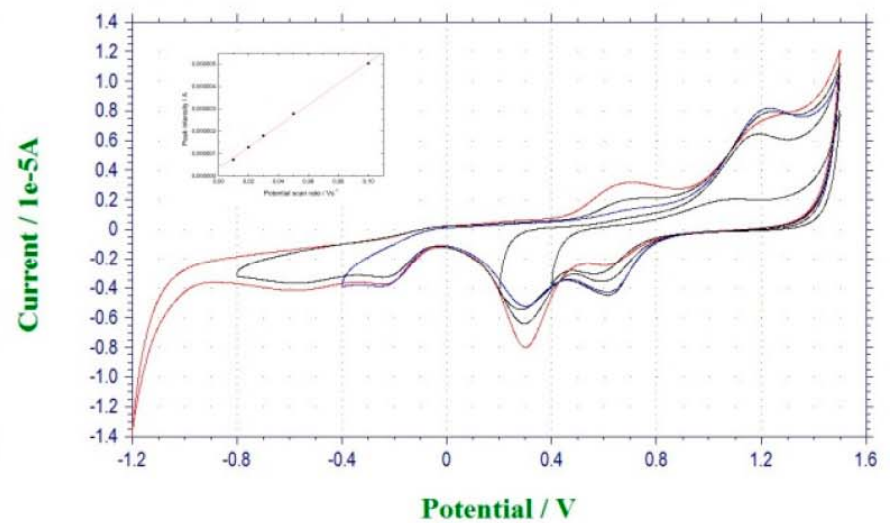

b)

Figure 2: Voltammetric profiles of $A u-p c$ in $0.1 \mathrm{mg} / \mathrm{mL}$ phycocyanin solutions in $0.05 \mathrm{M} \mathrm{NaClO}_{4}, v=0.1 \mathrm{Vs}^{-1}$. a) Superimposed to the obtained profile for $0.05 \mathrm{M} \mathrm{NaClO}_{4}$ solution (blue line, supporting electrolyte). b) for potential scans between $\mathrm{E}_{\mathrm{i}}=-1.2$ to $0.4 \mathrm{~V}$ and $\mathrm{E}_{\mathrm{f}}=1.5 \mathrm{~V}$. c) Intensity of the current peak at ca. $1.2 \mathrm{~V}$ vs. potential scan rate representation, showing the lineal adjust due to adsorption of the specie (inset). 


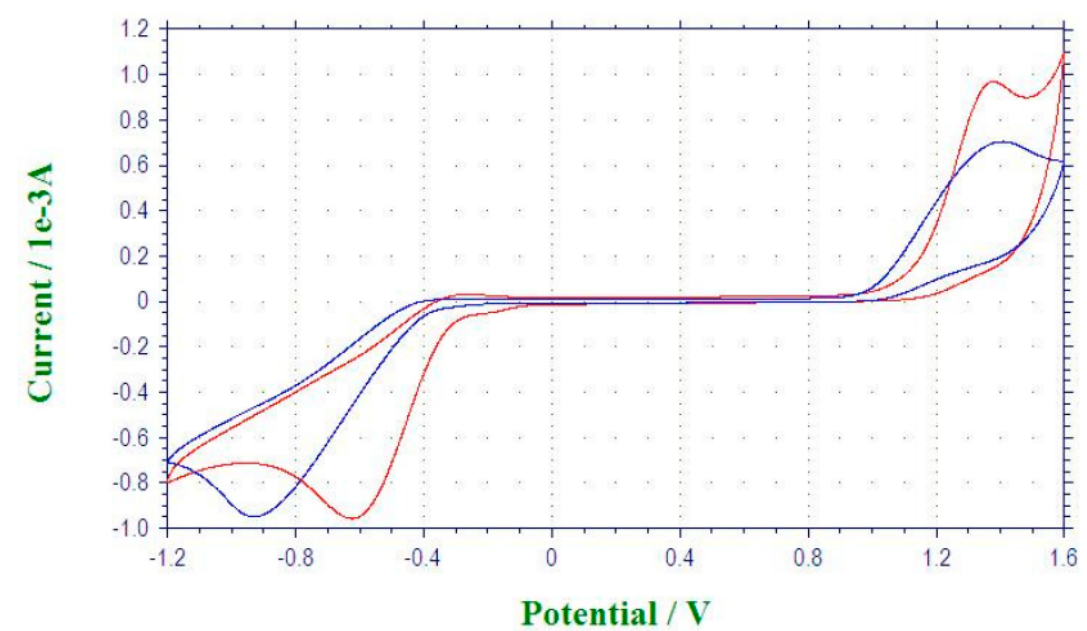

Figure 3: Voltammetric profiles of FTO in $0.1 \mathrm{mg} / \mathrm{mL}$ phycocyanin solutions in $0.05 \mathrm{M} \mathrm{NaClO}_{4}, v=0.1 \mathrm{Vs}^{-1}$, superimposed to the obtained profile for $0.05 \mathrm{M} \mathrm{NaClO}_{4}$ solution (blue line, supporting electrolyte).

chromophore of the protein the peak is absent, and can only be observed when the surface is clean, that is, when enough negative desorption potentials (ca. -0.8 V) are achieved.

The hypothesis can be confirmed using FTO as working electrode. On this surface the adsorption processes are not possible, and voltammetric profiles show less redox contributions.

As showed in Figure 3, using FTO it is possible to detect a contribution at ca. $1.3 \mathrm{~V}$ related to the irreversible oxidation to $\mathrm{CO}_{2}$.

In summary, phycocyanin has an oxidation peak at ca. $1.2 \mathrm{~V}$ vs. $\mathrm{Ag} / \mathrm{AgCl}$, and considering also the $\mathrm{E}_{0,0}$ value of $1.96 \mathrm{eV}$, the Rehm-Weller equation can be applied [46-48]. The predicted oxidation potential for the excited state of the phycocyanin will be $-0.76 \mathrm{~V}$, coming from the difference between the oxidation potential and the $\mathrm{E}_{0-0}$ value.

$\mathrm{TiO}_{2}$

Phycocyanin

$\mathbf{I}^{-/} \mathbf{I}^{-}$

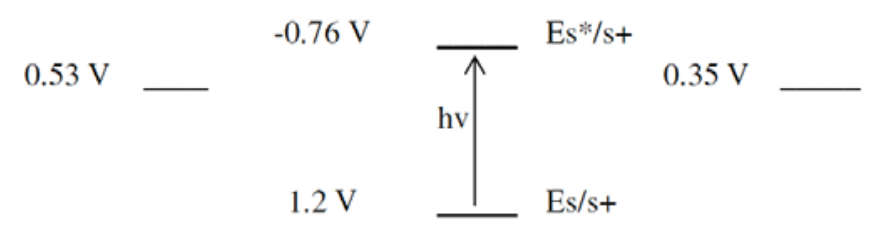

Scheme 1: Energy levels for the DSSC based in phycocyanin as natural dye.

According to this equation, and also taking a $0.53 \mathrm{~V}$ value for the conduction potential of $\mathrm{TiO}_{2}$, it is possible to predict a spontaneous process of electron transference between the blue protein and the $\mathrm{TiO}_{2}$.
With these values in mind, it can be deduced that upon excitation, phycocyanin reaches an $\mathrm{E}=-0.76 \mathrm{~V}$. Taking into account the latter value in comparison with the $0.53 \mathrm{~V}$ of $\mathrm{TiO}_{2}$, electron transfer processes between the excited dye [Dye] $]^{\star}$ and the semiconductor should be favorable from a thermodynamically point of view. On the other hand, if a value of $0.35 \mathrm{~V}$ for $\mathrm{I}^{-} / \mathrm{I}_{3}{ }^{-}$is also considered, the regeneration of the oxidized dye on the counter electrode surface would also take place. The first step, involves the oxidation of the dye as a consequence of the incident light followed by an electron transfer from the excited dye to the semiconductor, and certainly allows the switch on of the cell. The photoelectrochemical cycle will be completed by the last step that involves the regeneration of the dye due to the iodine species (Scheme 2). These will allow reusing the dye in later cycles.

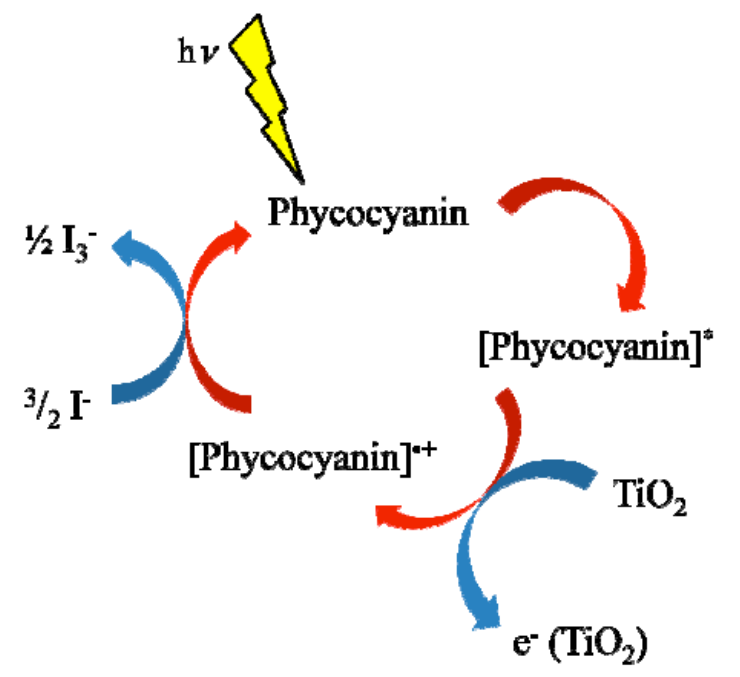

Scheme 2: Photoelectrochemical-cycle showing the whole redox steps triggered by the incident light. 


\subsection{Stability Measurements}

Stabilities of aqueous solutions of phycocyanin were evaluated against variable temperature and also with increasing amounts of $\mathrm{Nal}$, 3-methoxy propionitrile and ethylene glycol. In all cases, the studies were conducted by absorption spectroscopy by following the absorbance of the solution at $620 \mathrm{~nm}$.

With temperature a typical denaturalization behavior is observed. The absorbance at $620 \mathrm{~nm}$ shows a sigmoid behavior with temperature with an inflexion point at $50 \stackrel{\circ}{\circ}$. When the phycocynin containing solution reaches this temperature, half of the protein is at the native form and half is denaturized, in accordance with a thermodynamic equilibrium where only native and denaturized forms of the protein exists. At $90{ }^{\circ} \mathrm{C}$, the absorbance reaches the $25 \%$ of the initial value.

The effect of increasing amounts of Nal was also investigated and no significant changes were observed within the $0-0.5 \mathrm{M}$ concentration range. When [Nal] reached $3.0 \mathrm{M}$ value, absorbance of the protein solution decreased to $60 \%$ of the initial value. At [Nal] $=1.08 \mathrm{M}$, equimolar quantities of native and denaturized phycocyanin are present.

In case of the solvents, the absorbance shows a sigmoid decrease with increasing amounts of both tested solvents (i.e., 3-methoxypropionitrile and ethylene glycol). In particular, for a mixture 3methoxypropionitrile/water 40/60 (v:v) the absorbance represents $50 \%$ of the initial value in water, whereas for a mixture $40 / 60$ ethylene glycol/water the absorbance is the $85 \%$ of the initial value. Equimolar quantities of native and denaturized phycocyanin are present for mixtures 20/80 non-aqueous solvent/water.

It is important to point out that the chromophore is responsible for the high absorbance of phycocyanin. The native form has near the same ability than the denaturized form of the protein to absorb light at 620 $\mathrm{nm}$. It is expected that changes in the environment of the protein associated to denaturalization process does not significantly affect the absorptive features of the chromophore.

Summarizing, even in the worst conditions, which is

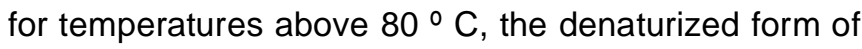
the protein shows interesting absorptive ability in the selected wavelength. We can assume therefore that the light harvesting ability of the dye will prevail at the experimental conditions usually observed in DSS cells, namely ['] lower than $0.5 \mathrm{M}$ in 3-methoxypropionitrile or ethylene glycol.

To further support the latter results, the stability of phycocyanin was also investigated by fluorescence emission spectroscopy. In particular, quenching experiments were also carried out in the presence of increasing amount of $\mathrm{Nal}$ (concentration ranging from 0 to $3.0 \mathrm{M}$ ). This salt was also selected because iodide is commonly used as component of the electrolyte in DSCC. As shown in Figure 4, the addition of increased amounts of the iodide salt caused attenuation in the fluorescence intensity. The $\mathrm{I} / \mathrm{I}_{0}$ variation can be represented and from this behavior it can be deduced

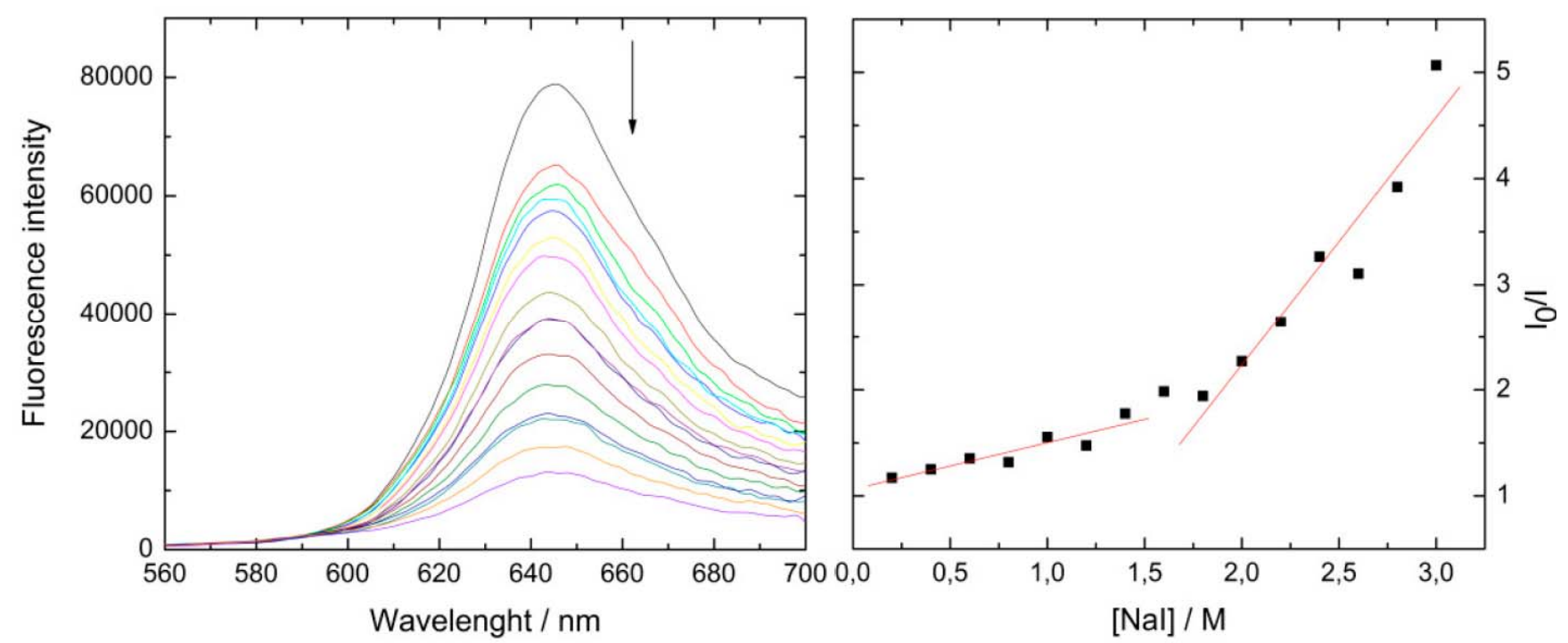

Figure 4: Quenching of the fluorescence of phycocyanin by Nal (left side). Stern-Volmer plot of the fluorescence intensities (right side). Nal concentration ranged between $0 \mathrm{M}$ and $3.0 \mathrm{M}$. Excitation wavelength $=530 \mathrm{~nm}$. 
that protein denaturalization is noticeable from $1.5 \mathrm{M}$ [46-49]. This behavior is in accordance with that observed using absorption spectroscopy, where concentration of native form of the protein clearly decreased at [Nal] higher than $1.1 \mathrm{M}$ (see discussion above).

\section{CONCLUSION}

Phycocyanin shows promising characteristics for its use as sensitizer in DSS cells, with high molar absorption coefficients at $620 \mathrm{~nm}$.

Spectroscopic and cyclic voltammetric measurements presented herein provide useful information to predict the potential use of phycocyanin as dye in DSS cells. According to our results, it can be deduced that upon excitation phycocyanin reaches an $\mathrm{E}=-0.76 \mathrm{~V}$. Therefore, from a thermodynamical point of view electron transfer reactions from the dye to the semiconductor $\mathrm{TiO}_{2}$ (with an $\mathrm{E}$ value of $0.53 \mathrm{~V}$ ) are possible. Moreover, taking into account a value of 0.35 $\mathrm{V}$ for the $\mathrm{I}^{-} / \mathrm{I}_{3}$ redox couple the regeneration of the oxidized dye on the counter electrode is also predictable.

The stability of the protein is also another remarkable and interesting point of phycocyanin that deserve to be highlighted, because under conditions of electrolyte concentration or in the present of the solvents commonly used in this type of cells, the loss in absorbance due to the protein denaturalization is very low. Only at high temperatures, the absorbance decreases significantly, but extinction coefficients are still high enough for the use in the cells.

\section{AKNOWLEDGEMENTS}

Authors would like to thank ANII-Uruguay (FSE_1_2011_6156) and PEDECIBA-Química (Uruguay). JG, PD and MFC are ANII researchers. PE has a CAP-UdelaR grant. FMC is a research member of CONICET-Argentina. FMC thanks DAAD for the spectrofluorometer Fluoromax4-HORIBA provided in the framework of Equipment Grants for Higher Education and Comparable Scientific and Research Institutions in Developing Countries.

\section{REFERENCES}

[1] Smestad GP. Education and solar conversion: Demonstrating electron transfer. Sol Energ Mat Sol C 1998; 55: 157-78.

http://dx.doi.org/10.1016/S0927-0248(98)00056-7
Smestad GP, Grätzel M. Demonstrating Electron Transfer and Nanotechnology: A Natural Dye-Sensitized Nanocrystalline Energy Converter. J Chem Educ 1998; 75: $752-6$.

http://dx.doi.org/10.1021/ed075p752

[3] Ito S, Murakami TN, Comte P, Liska P, Grätzel C, Nazeeruddin MK, et al. Fabrication of thin film dye sensitized solar cells with solar to electric power conversion efficiency over 10\%. Thin Solid Films 2008; 516: 4613-9.

http://dx.doi.org/10.1016/j.tsf.2007.05.090

[4] Wang X-F, Xiang J, Wang P, Koyama Y, Yanagida S, Wada $\mathrm{Y}$, et al. Dye-sensitized solar cells using a chlorophyll a derivative as the sensitizer and carotenoids having different conjugation lengths as redox spacers. Chem Phys Lett 2005; 408: 409-14.

http://dx.doi.org/10.1016/i.cplett.2005.04.067

[5] Bisquert J, Cahen D, Hodes G, Rühle S, Zaban A. Physical Chemical Principles of Photovoltaic Conversion with Nanoparticulate, Mesoporous Dye-Sensitized Solar Cells. J Phys Chem B 2004; 108: 8106-11.

\section{http://dx.doi.org/10.1021/jp0359283}

[6] Bisquert J, Grätzel M, Wang Q, F.Fabregat-Santiago. ThreeChannel Transmission Line Impedance Model for Mesoscopic Oxide Electrodes Functionalized with a Conductive Coating. J Phys Chem B 2006; 110: 11284-90. http://dx.doi.org/10.1021/jp0611727

[7] Ito S, Dharmadasa IM, Tolan GJ, Roberts JS, Hill G, Miura H, et al. High-voltage (1.8 V) tandem solar cell system using a GaAs/AIXGa(1-X)As graded solar cell and dye-sensitised solar cells with organic dyes having different absorption spectra. Solar Energy 2011; 85: 1220-5.

http://dx.doi.org/10.1016/j.solener.2011.02.024

[8] Gao F, Wang Y, Shi D, Zhang J, Wang MK, Jing XY, et al. Enhance the Optical Absorptivity of Nanocrystalline $\mathrm{TiO} 2$ Film with High Molar Extinction Coefficient Ruthenium Sensitizers for High Performance Dye-Sensitized Solar Cells. J Am Chem Soc 2008; 130: 10720-8. http://dx.doi.org/10.1021/ja801942

[9] Cao YM, Bai Y, Yu QJ, Cheng YM, Liu S, Shi D, et al. DyeSensitized Solar Cells with a High Absorptivity Ruthenium Sensitizer Featuring a 2-(Hexylthio)thiophene Conjugated Bipyridine. J Phys Chem C 2009; 113: 6290-7. http://dx.doi.org/10.1021/jp9006872

[10] Chen CY, Wang MK, J.Y. Li NP, Alibabaei L, Ngoc-le CH, Decoppet JD, et al. Highly Efficient Light-Harvesting Ruthenium Sensitizer for Thin-Film Dye-Sensitized Solar Cells. ACS Nano 2009; 3: 3103-9. http://dx.doi.org/10.1021/nn900756s

[11] Wang P, Yu QJ, Wang YH, Yi ZH, Zu NN, Zhang J, et al. High-efficiency dye-sensitized solar cells: The influence of lithium ions on exciton dissociation, charge recombination, and surface states. ACS Nano 2010; 4: 6032-8.

http://dx.doi.org/10.1021/nn101384e

[12] Yella A, Lee H-W, Tsao HN, Yi C, Chandiran AK, Nazeeruddin MK, et al. Porphyrin-Sensitized Solar Cells with Cobalt (II/III)-Based Redox Electrolyte Exceed 12 Percent Efficiency. Science 2011; 334(6056): 629-34. http://dx.doi.org/10.1126/science.1209688

[13] Grätzel C, Zakeeruddin SM. Recent trends in mesoscopic solar cells based on molecular and nanopigment light harvesters. Mater Today 2013; 16(1-2): 11-8. http://dx.doi.org/10.1016/j.mattod.2013.01.020

[14] Yum J-H, Moon S-J, Karthikeyan CS, Wietasch H, Thelakkat $\mathrm{M}$, Zakeeruddin SM, et al. Heteroleptic ruthenium complex containing substituted triphenylamine hole-transport unit as sensitizer for stable dye-sensitized solar cell. Nano Energy 2012; 1: 6-12.

http://dx.doi.org/10.1016/i.nanoen.2011.08.004

[15] Dwivedi C, Dutta V, Chandiran AK, Nazeeruddin MK, Grätzel M. Anatase $\mathrm{TiO} 2$ Hollow Microspheres Fabricated by 
Continuous Spray Pyrolysis as a Scattering Layer in DyeSensitised Solar Cells. Energy Procedia 2013; 33: 223-7. http://dx.doi.org/10.1016/j.egypro.2013.05.061

[16] Calogero G, Yum J-H, Sinopoli A, Marco GD, Grätzel M, Nazeeruddin MK. Anthocyanins and betalains as lightharvesting pigments for dye-sensitized solar cells. Solar Energy 2012; 86: 1563-75.

http://dx.doi.org/10.1016/j.solener.2012.02.018

[17] Hao S, Wu J, Huang Y, Lin J. Natural dyes as photosensitizers for dye-sensitized solar cell. Solar Energy 2011; 80: 209-14.

http://dx.doi.org/10.1016/j.solener.2005.05.009

[18] Zhou H, Wu L, Gao Y, Ma T. Dye-sensitized solar cells using 20 natural dyes as sensitizers. J Photochem Photobiol A Chem 2011; 219: 188-94. http://dx.doi.org/10.1016/j.jphotochem.2011.02.008

[19] Li Y, Ku S-H, Chen S-M, Ali MA, AlHemaid FMA. Photoelectrochemistry for Red Cabbage Extract as Natural Dye to Develop a Dye-Sensitized Solar Cells. Int $\mathrm{J}$ Electrochem Sci 2013; 8: 1237-45.

[20] Calogero G, Marco GD. Red Sicilian orange and purple eggplant fruits as natural sensitizers for dye-sensitized solar cells. Sol Energ Mat Sol C 2008; 92: 1341-6.

http://dx.doi.org/10.1016/i.solmat.2008.05.007

[21] Al-Bat'hi SAM, Alaei I, Sopyan I. Natural Photosensitizers for Dye Sensitized Solar Cells. Int J Renewable En Res 2013; 3(1).

[22] Rowan KS, Ed. Photosynthetic Pigments of Algae. Cambridge: Cambridge Univ. Press 1989.

[23] Bahadar A, Bilal Khan $M$. Progress in energy from microalgae: A review. Renew Sust Energ Rev 2013; 27(0): 128-48.

http://dx.doi.org/10.1016/j.rser.2013.06.029

[24] Brennan L, Owende P. Biofuels from microalgae-A review of technologies for production, processing, and extractions of biofuels and co-products. Renew Sust Energ Rev 2010; 14(2): 557-77.

http://dx.doi.org/10.1016/j.rser.2009.10.009

[25] Dębowski M, Zieliński M, Grala A, Dudek M. Algae biomass as an alternative substrate in biogas production technologies—Review. Renew Sust Energ Rev 2013; 27(0): 596-604.

http://dx.doi.org/10.1016/i.rser.2013.07.029

[26] Kirrolia A, Bishnoi NR, Singh R. Microalgae as a boon for sustainable energy production and its future research \&amp; development aspects. Renew Sust Energ Rev 2013; 20(0): 642-56.

http://dx.doi.org/10.1016/j.rser.2012.12.003

[27] Oncel SS. Microalgae for a macroenergy world. Renew Sust Energ Rev 2013; 26(0): 241-64. http://dx.doi.org/10.1016/j.rser.2013.05.059

[28] Pragya N, Pandey KK, Sahoo PK. A review on harvesting, oil extraction and biofuels production technologies from microalgae. Renew Sust Energ Rev 2013; 24(0): 159-71. http://dx.doi.org/10.1016/j.rser.2013.03.034

[29] Ramachandra TV, Durga Madhab M, Shilpi S, Joshi NV. Algal biofuel from urban wastewater in India: Scope and challenges. Renew Sust Energ Rev 2013; 21(0): 767-77. http://dx.doi.org/10.1016/j.rser.2012.12.029

[30] Razzak SA, Hossain MM, Lucky RA, Bassi AS, de Lasa H. Integrated $\mathrm{CO} 2$ capture, wastewater treatment and biofuel production by microalgae culturing-A review. Renew Sust Energ Rev 2013; 27(0): 622-53. http://dx.doi.org/10.1016/j.rser.2013.05.063

[31] Singh J, Gu S. Commercialization potential of microalgae for biofuels production. Renew Sust Energ Rev 2010; 14(9): 2596-10.

http://dx.doi.org/10.1016/j.rser.2010.06.014
[32] Suali E, Sarbatly R. Conversion of microalgae to biofuel. Renew Sust Energ Rev 2012; 16(6): 4316-42. http://dx.doi.org/10.1016/j.rser.2012.03.047

[33] Adenle AA, Haslam GE, Lee L. Global assessment of research and development for algae biofuel production and its potential role for sustainable development in developing countries. Energy Policy 2013; 61(0): 182-95 http://dx.doi.org/10.1016/j.enpol.2013.05.088

[34] Cruz RVAd, Nascimento CAOd. Emergy analysis of oil production from microalgae. Biomass Bioenergy 2012; 47(0): 418-25.

[35] Sydney EB, da Silva TE, Tokarski A, Novak AC, de Carvalho JC, Woiciecohwski AL, et al. Screening of microalgae with potential for biodiesel production and nutrient removal from treated domestic sewage. Appl Energy 2011; 88(10): 3291-4. http://dx.doi.org/10.1016/j.apenergy.2010.11.024

[36] Heller BA, Gindt YM. A biochemical study of noncovalent forces in proteins using phycocyanin from Spirulina. J Chem Education 2000; 77: 1458-9.

http://dx.doi.org/10.1021/ed077p1458

[37] Taylor ATS, Feller SE. Structural studies of phycobiliproteins from Spirulina: combining spectroscopy, thermodynamics, and molecular modeling in an undergraduate biochemistry experiment. J Chem Educ 2002; 79: 1467-70.

http://dx.doi.org/10.1021/ed079p1467

[38] Vignoni M, Rasse-Suriani FAO, Butzbach K, Erra-Balsells $\mathrm{R}$ Epe B, Cabrerizo FM. Mechanisms of DNA damage by photoexcited 9-methyl- $\beta$-carbolines. OrgBiomolChem 2013; 11: 5300-9.

http://dx.doi.org/10.1039/c3ob40344k

[39] Gonzalez MM, Arnbjerg J, Denofrio MP, Erra-Balsells R, Ogilby PR, Cabrerizo FM. One- and two-photon excitation of $\beta$-carbolines in aqueous solution: $\mathrm{pH}$-dependent spectroscopy, photochemistry and photophysics. J Phys Chem A 2009; 113: 6648-56.

http://dx.doi.org/10.1021/jp902105x

[40] Seibert M, Connolly JS. Fluorescence properties of CPhycocyanin isolated from a thermophilic cyanobacterium. Photochem Photobiol 1984; 40: 267-71. http://dx.doi.org/10.1111/j.1751-1097.1984.tb04585.x

[41] Ogura K, Kobayashi M, Nakayama M, Miho Y. In-situ FTIR studies on the electrochemical oxidation of histidine and tyrosine. J Electroanal Chem 1999; 463: 218-23. http://dx.doi.org/10.1016/S0022-0728(98)00458-6

[42] Ogura K, Kobayashi M, Nakayama M, Miho Y. Electrochemical and in situ FTIR studies on the adsorption and oxidation of glycine and lysine in alkaline medium. J Electroanal Chem 1998; 449: 101-9. http://dx.doi.org/10.1016/S0022-0728(98)00015-1

[43] Wieckowski A, Sobkowski J, Zelenay P, Franaszczuk K. Adsorption of acetic acid on platinum, gold and rhodium electrodes. Electrochim Acta 1981; 26.

[44] Xiao X-Y, Sun S-G. Electrosorption of p-nitrobenzoic acid at a gold electrode in perchloric acid solutions studied by using cyclic voltammetry, EQCM, in situ FTIRS and Raman spectroscopy. Electrochim Acta 2000; 45: 2897-902. http://dx.doi.org/10.1016/S0013-4686(00)00365-0

[45] Cerdá MF, Méndez E, Malacrida L, Zinola CF, Melian C Martins $\mathrm{ME}$, et al. Redox Behavior of $\operatorname{Re}(\mathrm{V})-$ Amino Acid Containing Complexes. J Colloid Interface Sci 2002; 249: 366-71.

http://dx.doi.org/10.1006/jcis.2002.8228

[46] Kathiravan A, Chandramohan M, Renganathan R, Sekar S. Cyanobacterial chlorophyll as a sensitizer for colloidal TiO2. Spectrochim Acta Part A 2009; 71: 1783-7. http://dx.doi.org/10.1016/j.saa.2008.06.031

[47] Kathiravan A, Anbazhagan V, Jhonsi MA, Renganathan R Fluorescence quenching of meso-tetrakis (4-sulfonatophenyl) 
porphyrin by colloidal TiO2. Spectrochim Acta Part A 2008;

70: $615-8$.

http://dx.doi.org/10.1016/j.saa.2007.08.007

[48] Jhonsi MA, Kathiravan A, Paramaguru G, Manivannan C, Renganathan R. Fluorescence Quenching of Tris(2,2-
bipyridine)Ruthenium(II) Dichloride by Certain Organic Dyes. J Solution Chem 2010; 39: 1520-30. http://dx.doi.org/10.1007/s10953-010-9594-x

[49] Huang H, Zhou J, Zhou Y, Zhou Y, Feng Y, editors. Studies on the Photoinduced Interaction between $\mathrm{Zn}$ (II) Porphyrin and Colloidal TiO2: Hindawi Publishing Corporation 2010. 